\title{
Role Stress and Work Engagement as Antecedents of Job Satisfaction in Spanish Workers
}

\author{
Alejandro Orgambídez-Ramos ${ }^{1}$, Yolanda Borrego-Alés ${ }^{2}$, Isabel Mendoza-Sierra² \\ ${ }^{1}$ Algarve University (Portugal) \\ ${ }^{2}$ University of Huelva (Spain) \\ aoramos@uals.pt,_bborrego@ubu.es,imendoza@ubu.es
}

Received: November 2013

Accepted: March 2014

\section{Abstract:}

Purpose: According to the Job Demands-Resources (JDR) model, engagement and job satisfaction may be produce by two types of working conditions: job demands (i.e. role stress) and job resources (i.e. self-efficacy). This study examines the role of role stress and work engagement as antecedents of job satisfaction in a sample of Spanish workers.

Design/methodology/approach: This study comprised a sample of 435 Spanish workers. A cross sectional study was used to examine the relationship between role stress, work engagement and job satisfaction. Data were gathered based on personal administered questionnaires.

Findings and Originality/value: Hierarchical multiple regression models have revealed that job satisfaction was significantly predicted by role stress and work engagement. Results support JDR model by showing that positive outcomes, such as job satisfaction can be predicted by motivational process and job demands.

Research limitations/implications: The cross-sectional design cannot evidence of causal relationships. This study relies on self-reports, which might increase the risk of common method variance. 
Practical implications: On a practical level, the JDR model provides a framework for understanding motivating workplaces and engaged and satisfied employees.

Originality/value: The JDR model could be useful in designing strategies for which engaged employees may be advantageous to improving the quality of services, while at the same time increasing employees' job satisfaction and well-being.

Keywords: work engagement, role conflict, role ambiguity, job satisfaction, JDR model

\section{Introduction}

The Job Demands-Resources (JDR) model is a theoretical framework that tries to integrate two fairly independent research traditions: the stress research tradition and the motivation research tradition. According to the JDR model, whereas every occupation may have its own specific risks factors arrogated with job stress, these factors can be classified in two general categories (i.e. job demands and job resources). Job demands are initiators of a health impairment process and job resources are initiators of a motivational process. In addition, the model specifies how demands and resources interact, and predict important outcomes such as job satisfaction or organizational commitment. Previous research has shown that the assumptions of the model hold not only for self-reports but also for objective data. Moreover, studies have shown that JDR model can predict the experience of burnout and of work engagement (Bakker, Demerouti \& Verbeke, 2004; Demerouti \& Baker, 2011).

Recently, there has been a great deal of interest in employee engagement. Many have claimed that employee engagement predicts employee outcomes, organizational success, financial performance (e.g. total shareholder return), and client satisfaction (Chaudhary, Rangnekar \& Barua, 2011). The experience of engagement has been described as a fulfilling positive workrelated experience and state of mind (Bakker et al., 2004), and has been found to be related to good health and positive work affect, such as job satisfaction (Alarcon \& Lyons, 2011; Maslach \& Leiter, 2008; Schaufeli \& Bakker, 2004). In the current economic climate, the employees' psychological connection with their work is certainly a key to compete effectively (Chaudhary et al., 2011). The organizations are in need of employees who are engaged with their work (Bakker, van Veldhoven \& Xanthopoulou, 2010).

On the other hand, job stress has been recognized as a significant occupational hazard that can impair physical health, psychological well-being, and work performance. It is assumed that job stress is a mediator between the impact of external job demands (stressors such as role stress) and work-related outcomes (such as job insatisfaction, absenteeism, or illness) (Maslach \& Leiter, 2008). 
A variable closely associated with job stress and engagement in the research literature is job satisfaction. A number of writers have suggested that job satisfaction is of special significance, due to its relationships with other variables such as organizational commitment, intention to quit, and organizational citizenship behaviors (Alarcon \& Lyons, 20011; Saks, 2006; Yanhan, 2013). In this sense, this study examines the relationship between work engagement, role stress and job satisfaction, ant the role of work engagement and role stress as antecedents of job satisfaction in a sample of Spanish workers.

\subsection{The Job Demands-Resources Model}

At the heart of the JDR model lays the assumption that whereas every occupation may have its own specific risk factors associated with job stress, these factors can be classified in two general categories (i.e. job demands and job resources). Furthermore, the JDR model may be applied to various occupational settings, irrespective of the particular demands and resources involved (Bakker \& Demerouti, 2007, 2008). Job demands and job resources relate, in different ways, to positive and negative outcomes (Demerouti \& Bakker, 2011).

Job demands refer to those physical, psychological, social, or organizational aspects of the job that require sustained physical and/or psychological (cognitive and emotional) effort and skills, and are therefore associated with certain physiological and/or psychological costs. Examples are a high work pressure, an unfavorable physical environment, and emotionally demanding interactions with clients. Although job demands are not necessarily negative, they may turn into job stressors when meeting those demands requires high effort from which the employee has not adequately recovered. Instead, job resources refer to those physical, psychological, social, or organizational aspects of the job that either/or (1) reduce job demands and the associated physiological and psychological costs; (2) are functional in achieving work goals; and (3) stimulate personal growth, learning and development (Bakker \& Demerouti, 2007, 2008; Demerouti \& Bakker, 2011).

With regard to the relationship between demands-resources and personal and organizational outcomes, Maslach and Leiter (2008) hypothesized than the presence of specific demands (i.e. role stress) and the absence of specific resources (i.e. self-efficacy) predict burnout, leading to negative results such as job insatisfaction, absenteeism, and reduction of organizational commitment. Also, the JDR model predicts that while job demands are related to burnout, job resources are related to engagement.

Recent research has shown strong and positive relationships between job resources and work engagement, and negative relationships between job demands and work engagement. Several studies have revealed that job demands such as a high work pressure, emotional demands, and role stress may lead to exhaustion, disengagement, low job satisfaction, and impaired 
health (Bakker \& Demerouti, 2007), whereas job resources such as social support, performance feedback, and autonomy may instigate a motivational process, leading to jobrelated learning, job satisfaction, work engagement, and organizational commitment (Demerouti \& Bakker, 2011).

\subsection{Work engagement and job satisfaction}

Employee engagement has emerged as one way for organizations to measure the investment in human capital (Chaudhary et al., 2011). Engagement is defined as a motivational and positive construct related to work that is characterized by vigor, dedication, and absorption. Vigor is defined as high levels of energy and mental resilience while working, the willingness to invest effort in one's work, and persistence also in the face of difficulties. Dedication is characterized by a sense of significance, enthusiasm, inspiration, pride, and challenge. Vigor and dedication are considered as the core elements of engagement.

Finally, absorption is characterized by being fully concentrated and happily engrossed in one's work, whereby time passes quickly and one has difficulties with detaching oneself from work. Being fully absorbed in one's work comes close to what has been called 'flow', a state of optimal experience that is characterized by focused attention, clear mind, mind and body union, effortless concentration, complete control, loss of self-consciousness, distortion of time, and intrinsic enjoyment (Bakker et al., 2010; Demerouti \& Bakker, 2011; Llorens, Bakker, Schaufeli \& Salanova, 2006; Schaufeli \& Bakker, 2004). Work engagement helps individuals deal effectively to the demands of stressful work (Britt, Adler \& Bartone, 2001).

According to Saks (2006), there is reason to expect employee engagement to be related to individuals+ attitudes (i.e. job satisfaction), intentions, and behaviors. Kahn (1992) proposed that engagement leads to both individual outcomes (i.e. quality of people's work and their own experiences of doing that works), as well as organizational-levels outcomes (i.e. the growth and productivity of organizations). The experience of engagement has been described as a fulfilling positive work-related experience and state of mind (Schaufeli \& Bakker, 2004; Sonnentag, Mojza, Demerouti \& Bakker, 2012) and has been found to be related to good health and positive work affect, such as job satisfaction (Sonnentag et al., 2012).

\subsection{Role stress and job satisfaction}

Role stress is one of the most studied job demands in the literature. Role conflict and role ambiguity have been identified as organizational facts associated with burnout, conceptually the opposite of job satisfaction (Cervoni \& DeLucia-Waack, 2011). Role conflict is defined as the simultaneous occurrence of two or more role pressures, so that the compliance with one 
makes more difficult to comply with the other (Rizzo, House \& Lirtzman, 1970). According to Ivancevich and Mateson (1980), conflict occurs when more than one role pressure is exerted on an employee, and these two roles conflict with each other. Increased role obligations have shown to cause psychological conflict when multiple roles cannot be fulfilled. Other studies have found that excessive roles increase the likelihood of psychological stress (Bekker, De Jong, Zijlstra \& Van Landeghem, 2000).

Often role ambiguity is strongly connected with role conflict, and the two topics are researched together. Role ambiguity is described as a type of inadequacy where clear information is lacking regarding the expectation associated with a role. Ambiguous role expectations (subjective) are associated with greater tension and less job satisfaction than clear role expectations (Vandenberghe, Panaccio, Bentein, Mignonac \& Roussel, 2011).

A general definition of job satisfaction is how much one is find of one's job (Spector, 1997). Job satisfaction has been conceptualized as an appraisal of one's job (i.e. a cognitive variable), and affective reaction to one's job, or an attitude towards one's job (Spector, 1997; Weiss, 2002). As job satisfaction is a reaction directed toward the immediate work environment, an increase in role ambiguity and role conflict may precipitate the decline in job satisfaction. Both role ambiguity and role conflict constrain employees' ability to perform and be effective in their jobs, reducing enjoyment derived from the job (job satisfaction) (Vandenberghe et al., 2011). Several studios have supported the relationship between role conflict and role ambiguity and job satisfaction, specifically within teachers, nurses, and services staff (Cervoni \& DeLuciaWaack, 2011; Crawford, LePine \& Rich, 2010; Zapf, Seifert, Schmutte, Mertini \& Holz, 2001).

Job satisfaction is an important predictor of negative attitudes and behaviors in the work context. Given the negative consequences that may come with low levels of job satisfaction, it is necessary an analysis of the factors that determine job satisfaction, as well as the creation of programs that increase job satisfaction reducing, as a result, negative work behaviors. This is particular important in the actual Spanish economic context, with new innovative and professional requirement for employees but with scarcity of economic resources.

According to previous research, this study examines the relationship between work engagement, role stress (role conflict and role ambiguity) and job satisfaction, and the role of work engagement and role stress as antecedents of job satisfaction. It is hypothesized that: (1) there will be a negative relationship between work engagement and role stress; (2) work engagement will positively predict job satisfaction; and (3) role stress will negatively predict job satisfaction. 


\section{Method}

\subsection{Sample and procedures}

The field research was conducted over a four months period from September to December 2012. The sample consisted of 435 Spanish workers from public and private companies. As for the sample's socio-demographic characteristics, 52.5\% were women. The average age of the sample was 40.50 years old $(S D=10.15) .49 .5 \%$ of the participants held an undergraduate degree.

A cross sectional study using questionnaires was conducted. A three-page survey questionnaire in Spanish was utilized as the survey instrument. Data were gathered based on personal administered questionnaires. All participants were required to have a minimum of one year's experience in their professional positions. They were informed of the study's objective and the confidentiality of their data, and they were asked to consent to participate.

\subsection{Measures}

All the constructs included in the analysis were assessed with perceptual self-report measures based on multi-items scales, whose psychometric properties are well established.

Socio-demographic information. In this section participants were asked to report age, gender, and educational level.

Work engagement. Work engagement was assessed with the Spanish version of the Utrech Work Engagement (UWES) (Schaufeli \& Bakker, 2004). The nine items were distributed into three dimensions: vigor (three items), dedication (three items), and absorption (three items). Responses to all items were made on a Likert-type scale ranging from 0 ("never") to 6 ("always"). High scores indicate high levels of engagement in the workplace. The Cronbach's Alpha coefficient for the scale was .93.

Role stress. To measure role stress, we utilized the Spanish version of the Role Stress Scale (Rizzo et al., 1970). The Role Stress Scale consists of 11 items distributed into two sub-scales: role ambiguity (six items) and role conflict (five items). Responses to all items were made on a Likert-type scale ranging from 1 ("not agree at all") to 5 ("very strongly agree"). High scores revelas a high presence of role stress in the employees. The internal consistency (Cronbach's Alpha) in this study was .82 and .88 for role ambiguity sub-scale and role conflict sub-scale, respectively.

Job satisfaction. Job satisfaction was assessed by the Job Satisfaction Scale (Meliá \& Peiró, 1989). Responses to the twelve-item scale were given on a Likert-type scale from 1 "extremely 
unsatisfied" to 7 "extremely satisfied". High scores reveal a high presence of job satisfaction in the employees. The internal consistency (Cronbach's Alpha) in this study was .91.

\subsection{Data analysis}

Data analysis was conducted using SPSS 20.0 statistical package for Windows. The correlations between the punctuations of the different instruments and the reliability coefficient of dimensions were obtained using Pearson's correlation and the coefficient of measurement. Hierarchical multiple regression were used to assess the ability of work engagement and role stress to predict levels of job satisfaction.

\section{Results}

\subsection{Preliminary analysis}

First of all, before testing the hypotheses, we examined the measurement models with all study variables: work engagement, role conflict, role ambiguity, and job satisfaction. Harman's one-factor test was conducted to test the presence of common method variance (CMV). All the variables items were entered into a exploratory factor analysis, using unrotated principal components factor analysis, and forcing to extract one factor. The factor emerged accounted for less than $50 \%$ of the variance $(30.6 \%)$. Thus, no general factor is apparent (Podsakoff, MacKenzie, Lee \& Podsakoff, 2003). While the results of this study do not preclude the possibility of common method variance, they do suggest that CMV is not a great concern and thus is unlikely to confound the interpretations of the results.

\subsection{Descriptive statistics}

Table 1 shows the means, standard deviations, skewness and kurtosis, and intercorrelations of all study variables. The mean score of the variables ranged from 2.45 to 4.61 . None of the variables had absolute skewness greater than 1 . Role ambiguity was skewed toward the positive, yet work engagement, job satisfaction and role conflict were slightly toward the negative.

\begin{tabular}{|l|c|c|c|c|c|c|c|c|} 
& M & SD & Skw & Kur & $\mathbf{1}$ & $\mathbf{2}$ & $\mathbf{3}$ & $\mathbf{4}$ \\
\hline 1. Engagement & 4.00 & 1.30 & -0.67 & -0.11 & 1 & & & \\
\hline 2. R. Conflict & 3.91 & 1.42 & -0.10 & -0.74 & $-.18^{* *}$ & 1 & & \\
\hline 3. R. Ambiguity & 2.45 & 1.04 & 0.79 & -0.05 & $-.34 * *$ & $.23 * *$ & 1 & \\
\hline 4. J. Satisfaction & 4.61 & 1.18 & -0.48 & -0.40 & $.44 * *$ & $-.35^{* *}$ & $-.50 * *$ & 1 \\
\hline
\end{tabular}

$* p<.05 * * p<.01$

Table 1. Descriptive statistics and correlations of all study scales 


\subsection{Testing the hypotheses}

As Table 1 shows, both role conflict and role ambiguity were negatively related to job satisfaction ( $r=-.35$ and $r=-.50$, respectively, $p<.01)$, and to work engagement $(r=-.18$ and $r=-.34$, respectively, $p<.01)$. On the opposite, there was a positive and significant $(p$ $<.01)$ relationship between work engagement and job satisfaction $(r=.44)$, so that the higher levels of work engagement and the lower levels of role stress in individuals, the higher job satisfaction.

Regression models were used to assess the ability of work engagement and role stress (role conflict and role ambiguity) to predict levels of job satisfaction. Preliminary analyses were conducted to ensure no violation of the assumptions of normality, linearity, multicollinearity, and homoscedasticity.

First, it was tested the ability of both role ambiguity and role conflict to predict levels of job satisfaction. The total variance explained by the Model 1 as a whole was $30.7 \%, F(2,427)=$ $94.784, p<.01$. Both role conflict and role ambiguity were statistically significant, with role ambiguity recording a higher beta value $(\beta=-.44, p<.01)$ than role conflict $(\beta=-.25, p<.01)$.

Next, hierarchical multiple regression models were used to assess the ability of work engagement to predict job satisfaction after controlling for the influence of role conflict and role ambiguity. Role conflict and role ambiguity were entered at Step 1, explaining 30.7\%. After entry of work engagement at Step 2, the total variance explained by the Model 2 as a whole was $37.5 \%, F(3,426)=85.08, p<.01$. Work engagement explained an additional $6.8 \%$ of the variance on job satisfaction, after controlling for the influence of role conflict and role ambiguity, $R$ squared change $=.067, F(1,426)=48.99, p<.01$. In the final model, all three variables were statistically significant, with the role ambiguity measure recording a higher beta value $(\beta=-.35, p<.01)$ than work engagement $(\beta=.28, p<.01)$ and role conflict $(\beta=-.22, p<.01)$.

\begin{tabular}{|l|c|c|c|c|}
\hline & B & SE B & Beta & t \\
\hline Step 1 & & & & \\
$\quad$ Cte & 2.26 & 0.36 & $-.44^{* *}$ & -10.62 \\
Role Ambiguity & -0.56 & 0.05 & $-.25^{* *}$ & -6.06 \\
Role Conflict & -0.21 & 0.03 & & \\
\hline Step 2 & & & & 5.17 \\
Cte & 1.79 & 0.35 & $-.35^{* *}$ & -8.47 \\
Role Ambiguity & -0.45 & 0.05 & $-.22^{* *}$ & -5.55 \\
Role Conflict & -0.18 & 0.03 & $.28^{* *}$ & 6.77 \\
Engagement & 0.25 & 0.04 & & \\
\hline
\end{tabular}

\footnotetext{
$* p<.05 * * p<.01$
}

Table 2. Hierarchical regression results for job satisfaction 


\section{Discussion}

Due to the current scarcity of economic resources, job satisfaction is of interest to researchers and practitioners. Now, more than ever, organizations need engaged and satisfied employees. This study investigated the relationship between work engagement, role stress and job satisfaction, and the role of engagement and role stress as antecedents of job satisfaction. The results support the JDR model in a sample of Spanish workers.

The results support the relationship between role stress and work engagement. Findings confirmed that role stress was negatively correlated to work engagement (Bakker et al., 2010; Demerouti \& Bakker, 2011; Schaufeli \& Bakker, 2004). An employee's engagement level will decrease when presented with increased stress. In addition, the JDR model found that as job demands (role stress) goes up, engagement goes down. Poorly designed job or chronic job demands exhaust employees' mental and physical resources, leading to the depletion of energy, absorption, and dedication related to engagement (Bakker \& Demerouti, 2007, 2008).

A positive and significant relationship between work engagement and job satisfaction was observed in this study. This result is in line with other research studies (Alarcon \& Lyons, 2011; Cervoni \& DeLucia-Waack, 2011; Yanhan, 2013), which have shown a positive relationship between engagement and job satisfaction, and a negative relationship between role stress (role ambiguity and role conflict) and job satisfaction.

Our results corroborate these findings and provide further evidence that job demands and job resources relate, in different ways, to positive and negative outcomes. According to the JDR model, there is a link between both demands and resources in the workplace and personal and organizational outcomes, such job satisfaction, engagement or burnout (Bakker et al., 2010; Schaufeli \& Bakkerm 2004).

This study suggests that engagement is a key predictor of job satisfaction. Our results are consistent with those found in other studies (Alarcon \& Lyons, 2011; Demerouti \& Bakker, 2011; Saks, 2006; Schaufeli \& Bakker, 2004; Simpson, 2009). Saks (2006) found work engagement had a positive relationship with employees' job satisfaction and a negative relationship with turnover intention. In a study of medical surgical nurses, Simpson (2009) found significant and positive correlations between employee engagement and job satisfaction among registered nurses. Nurses who had high levels of job satisfaction also reported high levels of work engagement.

The positive emotions related to engagement are likely to result in positive work outcomes, such as job satisfaction. According to Saks (2006), individuals who continue to engage themselves do so because of the continuation of favorable reciprocal exchanges. As a result, individuals who are more engaged are likely to be in more trusting and high-quality 
relationships with their employer and will, therefore, be more likely to report more positive attitudes and intentions toward the job and the organization.

With regard to role stress and job satisfaction, role conflict and role ambiguity have been identified as organizational factors associated to burnout and low job satisfaction (Cervoni \& DeLucia-Waack, 2011). Research further suggests that role stressors such role ambiguity and role conflict have negative relationships with job satisfaction (Podsakoff, LePine \& LePine, 2007). In this sense, our results show that both role conflict and role ambiguity were significant predictors of job satisfaction, as observed in other studies (Cervoni \& DeLuciaWaack, 2011; Podsakoff et al., 2007; Vandenberghe et al., 2011).

Work stressors are the stimuli that induce the stress process, and forms of strain, such as anxiety, tension, and exhaustion, are the proximal outcomes. Because strain is undesirable, it triggers negative emotions and cognitions, which ultimately translate into coping in the form of emotional and physical withdrawal from work, and affects attitudes towards work, such as job satisfaction (Podsakoff et al., 2007). These results are coherent with Shaubroeck's theory about stressors in the workplace. According to Schaubroeck, Cotton, and Jennings (1989), hindrance stressors (i.e. role ambiguity and role conflict) are positively related to strain, and have a direct negative effects on job satisfaction.

The multiple demands placed on the workplace appear to create pressure to make decisions on what tasks to do or how to provide all of them with finite resources and time. Also, ambiguity surrounding the role in the workplace creates pressure and influences negatively job satisfaction (Cervoni \& DeLucia-Waack, 2011). The tension at work caused by role ambiguity and role conflict had a significant negative impact on job satisfaction, suggesting that the less role stress the workers perceived, the more satisfaction they reported (Cervoni \& DeLuciaWaack, 2011; Crawford et al., 2010; Podsakoff et al., 2007; Zapf et al., 2001).

There are limitations to the study that have to be addressed. First, the cross-sectional nature of the study limited the findings in that we could not show evidence of causal relationships. Second, this study relies on self-reports, which might increase the risk of common method variance (CMV). Harman's one-factor test, however, indicated that CMV did not significantly influence our results (Podsakoff et al., 2003). Third, the sample size, among other factors, may affect sizes and the power of the results.

Future studies are to examine this model in other contexts and at different organizational levels, as well as in different samples. Larger samples would allow more sophisticated statistical analyses, testing the role of engagement as a mediator between role stress and job satisfaction.

To sum up, the JDR model provides a framework for understanding engaged employees and motivating workplaces. This framework could be useful in designing strategies for which 
engaged employees may be advantageous to improving the quality of services, while at the same time increasing employees' job satisfaction and well-being.

\section{References}

Alarcon, G.M., \& Lyons, J.B. (2011). The Relationship of Engagement and Job Satisfaction in Working Samples. Journal of Psychology, 145(5), 463-480.

http://dx.doi.org/10.1080/00223980.2011.584083

Bakker, A.B., \& Demerouti, E. (2007). The job demands-resources model: State of the art. Journal of managerial psychology, 22(3), 309-328. http://dx.doi.org/10.1108/02683940710733115

Bakker, A.B., \& Demerouti, E. (2008). Towards a model of work engagement. Career Development International, 13(3), 209-223. http://dx.doi.org/10.1108/13620430810870476

Bakker, A.B., Demerouti, E., \& Verbeke, W. (2004). Using the job demands-resources model to predict burnout and performance. Human Resource Management, 43(1), 83-104. http://dx.doi.org/10.1002/hrm.20004

Bakker, A.B., van Veldhoven, M., \& Xanthopoulou, D. (2010). Beyond the demand-control model: Thriving on high job demands and resources. Journal of Personnel Psychology, 9(1), 3. http://dx.doi.org/10.1027/1866-5888/a000006

Bekker, M.H., De Jong, P.F., Zijlstra, F.R., \& Van Landeghem, B.A. (2000). Combining care and work: Health and stress effects in male and female academics. International Journal of Behavioral Medicine, 7(1), 28-43. http://dx.doi.org/10.1207/S15327558IJBM0701_3

Britt, T.W., Adler, A.B., \& Bartone, P.T. (2001). Deriving benefits from stressful events: the role of engagement in meaningful work and hardiness. Journal of Occupational Health Psychology, 6(1), 53. http://dx.doi.org/10.1037/1076-8998.6.1.53

Cervoni, A., \& DeLucia-Waack, J. (2011). Role conflict and ambiguity as predictors of job satisfaction in high school counselors. Journal of School Counseling, 9(1), 1-30.

Chaudhary, R., Rangnekar, S., \& Barua, M. (2011). Relation between human resource development climate and employee engagement: Results from India. Europe's Journal of Psychology, 7(4), 664-685. http://dx.doi.org/10.5964/ejop.v7i4.158

Crawford, E.R., LePine, J.A., \& Rich, B.L. (2010). Linking job demands and resources to employee engagement and burnout: A theoretical extension and meta-analytic test. Journal of Applied Psychology, 95(5), 834. http://dx.doi.org/10.1037/a0019364

Demerouti, E., \& Bakker, A.B. (2011). The job demands-resources model: Challenges for future research. SA Journal of Industrial Psychology, 37(2), 1-9. http://dx.doi.org/10.4102/sajip.v37i2.974 
Ivancevich, J.M., \& Matteson, M.T. (1980). Stress and work: A managerial perspective. Tucker, GA: Scott, Foreman and Company.

Kahn, W.A. (1992). To be fully there: Psychological presence at work. Human Relations, 45(4), 321-349. http://dx.doi.org/10.1177/001872679204500402

Llorens, S., Bakker, A.B., Schaufeli, W., \& Salanova, M. (2006). Testing the robustness of the job demands-resources model. International Journal of Stress Management, 13(3), 378. http://dx.doi.org/10.1037/1072-5245.13.3.378

Maslach, C., \& Leiter, M.P. (2008). Early predictors of job burnout and engagement. Journal of Applied Psychology, 93(3), 498. http://dx.doi.org/10.1037/0021-9010.93.3.498

Meliá, J.L., \& Peiró, J.M. (1989). El cuestionario de satisfacción S10/12: Estructura factorial, fiabilidad y validez. Psicología del Trabajo y las Organizaciones, 11, 179-185.

Podsakoff, P.M., LePine, J.A., \& LePine, M.A. (2007). Differential challenge stressor-hindrance stressor relationships with job attitudes, turnover intentions, turnover, and withdrawal behavior: A meta-analysis. Journal of Applied Psychology, 92(2), 438-454.

http://dx.doi.org/10.1037/0021-9010.92.2.438

Podsakoff, P.M., MacKenzie, S.B., Lee, J.Y., \& Podsakoff, N.P. (2003). Common method biases in behavioral research: A critical review of the literature and recommended remedies. Journal of Applied Psychology, 88(5), 879-903. http://dx.doi.org/10.1037/0021-9010.88.5.879

Rizzo, J.R., House, R.J., \& Lirtzman, S.I. (1970). Role conflict and ambiguity in complex organizations. Administrative Science Quarterly, 150-163. http://dx.doi.org/10.2307/2391486

Saks, A.M. (2006). Antecedents and consequences of employee engagement. Journal of Managerial Psychology, 21(7), 600-619. http://dx.doi.org/10.1108/02683940610690169

Schaubroeck, J., Cotton, J.L., \& Jennings, K.R. (1989). Antecedents and consequences of role stress: A covariance structure analysis. Journal of Organizational Behavior, 10(1), 35-58. http://dx.doi.org/10.1002/job.4030100104

Schaufeli, W.B., \& Bakker, A.B. (2004). Job demands, job resources, and their relationship with burnout and engagement: A multi-sample study. Journal of Organizational Behavior, 25(3), 293-315. http://dx.doi.org/10.1002/job.248

Simpson, M.R. (2009). Engagement at work: A review of the literature. International Journal of Nursing Studies, 46(7), 1012-1024.http://dx.doi.org/10.1016/j.ijnurstu.2008.05.003

Sonnentag, S., Mojza, E.J., Demerouti, E., \& Bakker, A. (2012). Reciprocal relations between recovery and work engagement: The moderating role of job stressors. Journal of Applied Psychology, 97(4), 842-853. http://dx.doi.org/10.1037/a0028292 
Spector, P.E. (1997). Job satisfaction: Application, assessment, causes, and consequences. Thousand Oaks, CA: Sage.

Vandenberghe, C., Panaccio, A., Bentein, K., Mignonac, K., \& Roussel, P. (2011). Assessing longitudinal change of and dynamic relationships among role stressors, job attitudes, turnover intention, and well-being in neophyte newcomers. Journal of Organizational Behavior, 32(4), 652-671. http://dx.doi.org/10.1002/job.732

Weiss, H.M. (2002). Deconstructing job satisfaction: Separating evaluations, beliefs and affective experiences. Human Resource Management Review, 12(2), 173-194. http://dx.doi.org/10.1016/S1053-4822(02)00045-1

Yanhan, Z. (2013). A Review of Job Satisfaction. Asian Social Science, 9(1), 293-298. http://dx.doi.org/10.5539/ass.v9n1p293

Zapf, D., Seifert, C., Schmutte, B., Mertini, H., \& Holz, M. (2001). Emotion work and job stressors and their effects on burnout. Psychology \& Health, 16(5), 527-545. http://dx.doi.org/10.1080/08870440108405525

Journal of Industrial Engineering and Management, 2014 (www.jiem.org)

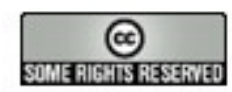

Article's contents are provided on a Attribution-Non Commercial 3.0 Creative commons license. Readers are allowed to copy, distribute and communicate article's contents, provided the author's and Journal of Industrial Engineering and Management's names are included. It must not be used for commercial purposes. To see the complete license contents, please visit http://creativecommons.org/licenses/by-nc/3.0/. 